\title{
AN AHP MODEL FOR SELECTING STRATEGIC OPTIONS
}

\author{
Sezi Çevik Onar* \\ Management Faculty \\ Istanbul Technical University \\ Macka, Istanbul, TURKEY \\ E-mail: sezicevik@yahoo.com \\ Seçkin Polat \\ Management Faculty \\ Istanbul Technical University \\ Macka, Istanbul, TURKEY \\ E-mail:polatsec@itu.edu.tr
}

\begin{abstract}
The high level of competition and uncertainty forced firms to make right and on time strategic decisions in order to survive. The management practices for the stable environments are not suitable for the new dynamic environment. In order to respond to this dynamic and uncertain environment, managers and academicians focused on the organization's strategic flexibility. According to the strategic options view the main property of strategic flexibility is the ability to access to the resources and capabilities when they are needed (Sanchez, 1997). Strategic flexibility is defined as "condition of having strategic options that are created through combined effects of an organization's coordination flexibility in acquiring and using flexible resources" (Sanchez, 1993). According to this definition in order to have strategic flexibility, firms need to have strategic options and the main task of the managers is to define, develop, acquire and coordinate the resources and competencies that will optimize the value of strategic options cluster. In order to optimize strategic options cluster managers should effectively manage competence building and competence leveraging processes. In order to have effective competence building and competence leveraging processes we should answer the questions "What are the factors effecting these processes"? However, the selection of a suitable strategic option is not an easy decision, involving a lot of complex considerations. Therefore this study focuses on the factors effecting the exercising decision of a strategic option. An analytical hierarchy process is applied to selecting strategic options that will be exercised.
\end{abstract}

Keywords: AHP, Strategic Options, Competence Building, Mergers and Acquisitions

\section{Introduction}

The developments in the recent years such as removal of cross border barriers in Europe; the globalization of product markets, the technology developments, and the change in the organization forms increased the competition among firms. This increased competition caused high level of changes in the firms' environment and uncertainty for organizations of all types. Competence building is defined as the qualitative change in firms' existing assets, capabilities; exercising strategic options will trigger this process. According to this definition the objective of strategic managers is to have valuable strategic options. The management of strategic options includes selecting valuable strategic options. 
Several researchers emphasized the relation between resources, capabilities and the strategic options. Kogut and Kulatilaka (2001) defined capabilities as real options which bring future opportunities. Bernardo and Chowdhry (2002) claimed that with the real investment decisions firms learn information about the different types of resources they have, therefore firms should consider this learning process while exercising their strategic options. Pandza et al. (2003) considered real options thinking as an appropriate heuristic for capability development. Kyläheiko and Sandström (2007) developed a framework for managing dynamic capabilities by using strategic options. Maritan and Alessandri (2007) also considered capabilities as real options. They revealed that industry based returns and firm specific returns are the components of returns to capability investment. Most of these studies are conceptual; there are little empirical evidences about these conceptual models.

Selecting strategic options that will be exercised is a multiple criteria problem. It includes both tangible and intangible factors also objective measurements and value judgments can be used to make the decision. This decision should include the behavioral aspects of decision making or the presence of multiple and conflicting objectives. Unfortunately managers lack the cognitive capacity to consider all environmental elements and they do not have enough time (Kasanen, et al., 2000) Several researchers applied MCDM methods for strategic management decisions such as selecting strategic alliances (Ding and Liang, 2005; Büyükozan et al., 2008; Cheng and Li, 2007 ); strategic planning (Chadrasekaran and Ramesh, 1987; Al-Shemmeri et al, 1997); strategic decision making (Islei et al., 1990; Firouzabadi, 2008). The factors that is important for selecting strategic options have a hierarchical order and also both includes tangible and intangible elements. Analytical hierarchy process can fulfill all the needs for such a problem (Saaty, 1980). Several researchers used Analytical Hierarchy Process in strategic evaluation (Datta, et. al.,1992; Bayazit, et al., 2006; Borenstein and Betencourt, 2005).This paper utilizes AHP approach for selecting a strategic option.

\section{The factors affecting the value of strategic options}

According to McGrath et al. (2004) the link between real options, the factors that are effecting these options and the performance is largely unexamined. Several researchers focused on the factors affecting the value of the strategic option that a firm is holding. For instance Sanchez (2003) by combining transaction cost theory and real options theory created a theoretical framework to explain the value created through the strategy under uncertainty. In his early study Kogut (1991) claimed that the joint ventures create real options to expand. In this study the effect of market growth on acquisition of the venture is evaluated. The results supported the interpretation of joint ventures as options to expand. Reuer and Leiblein (2000) analyzed the value of international investments as they expected to enhance corporate flexibility and reduce risk. The results indicate that these investments do not reduce the downside risk. Therefore they do not bring the flexibility they expected to bring. Tong and Reuer (2008) analyzed the firm and industry influences on the value of growth options. The results indicate that the industry effects are important but the firm effect is more dominant on the growth option value. McGrath and Nerkar (2004) utilized real option reasoning in analyzing R\&D investment strategies. The scope of opportunity, prior experience and competitive effects claimed to have effect on the value created by these options. Vassolo et al. (2004) considered the equity alliances as real options. The termination of these alliances whether by acquisition or divesture regarded as exercise decision and the researchers focused on the factors effecting this decision. O'Brien et al. (2003) investigated the effects of uncertainty and irreversibility on entrepreneurial entry with real options perspective. The results of the study show that high uncertainty deters the entry decision and irreversibility has a moderator effect on this decision. The factors affecting the value of strategic options can be classified as internal factors, environmental factors and decision related factors. Different studies focused on different factors and measure these factors differently.

Table 1 summarizes these factors in the literature. 
Table 1. Factors affecting strategic options

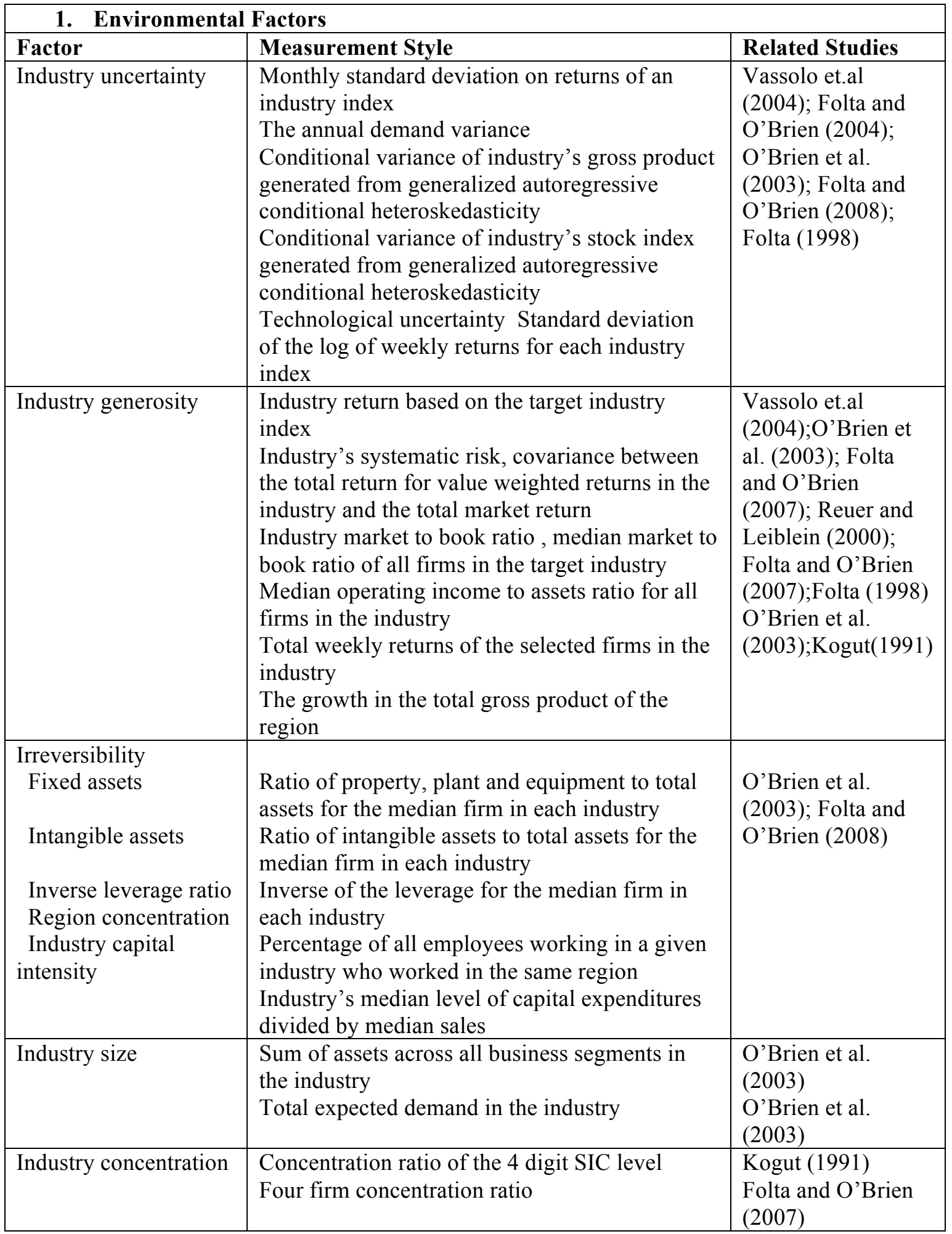




\begin{tabular}{|c|c|c|}
\hline Industry type & Dummy variable coded based on the industry & $\begin{array}{l}\text { Tong and Reuer } \\
\text { (2008), O'Brien et } \\
\text { al. (2003), Folta } \\
\text { (1998), Kogut } \\
(1991)\end{array}$ \\
\hline \multicolumn{3}{|c|}{ 2. Internal Factors } \\
\hline Firm's performance & $\begin{array}{l}\text { Total operating profit divided by total sales } \\
\text { Return on assets, operating profit divided by } \\
\text { assets } \\
\text { Accounts receivable divided by sales } \\
\text { Inventory divided by sales } \\
\text { Selling, general and administrative expenses } \\
\text { divided by sales }\end{array}$ & $\begin{array}{l}\text { O'Brien et al. } \\
\text { (2003); Folta and } \\
\text { O'Brien (2008); } \\
\text { Reuer and Leiblein } \\
\text { (2000) }\end{array}$ \\
\hline Firm size & $\begin{array}{l}\text { Logarithmic transaction of sales } \\
\text { Logarithmic total firm assets }\end{array}$ & $\begin{array}{l}\text { Vassolo et.al } \\
\text { (2004); Reuer and } \\
\text { Leiblein (2000); } \\
\text { Folta and O'Brien } \\
(2004)\end{array}$ \\
\hline $\begin{array}{l}\text { Firm's diversification } \\
\text { level }\end{array}$ & $\begin{array}{l}\text { Sum of squared shares of the firm's business } \\
\text { segments }\end{array}$ & $\begin{array}{l}\text { Folta and O'Brien } \\
\text { (2004); Folta and } \\
\text { O'Brien (2007b) }\end{array}$ \\
\hline $\begin{array}{l}\text { Firm's research and } \\
\text { development } \\
\text { (R\&D)intensity }\end{array}$ & Firm's R\&D expense divided by assets & $\begin{array}{l}\text { Folta and O'Brien } \\
(2008)\end{array}$ \\
\hline Firm's concentration & $\begin{array}{l}\text { Sum of the squared market shares of all business } \\
\text { segments competing in that industry }\end{array}$ & $\begin{array}{l}\text { O'Brien et al. } \\
(2003)\end{array}$ \\
\hline Founder's properties & $\begin{array}{l}\text { Formal education of firm's primary founder } \\
\text { Age of the entrepreneur } \\
\text { Dummy variable; coded } 1 \text { if the entrepreneur } \\
\text { was male }\end{array}$ & $\begin{array}{l}\text { O'Brien et al. } \\
\text { (2003) }\end{array}$ \\
\hline $\begin{array}{l}\text { Chief Executive } \\
\text { Officer (CEO) Duality }\end{array}$ & $\begin{array}{l}\text { Dummy variable; coded } 1 \text { if CEO is also } \\
\text { chairman of the board }\end{array}$ & $\begin{array}{l}\text { Folta and O’Brien } \\
\text { (2008) }\end{array}$ \\
\hline Inside ownership & $\begin{array}{l}\text { Percent of stock owned by insiders equity joint } \\
\text { ventures formed abroad or with a foreign partner }\end{array}$ & $\begin{array}{l}\text { Folta and O'Brien } \\
(2008)\end{array}$ \\
\hline $\begin{array}{l}\text { Number of large } \\
\text { blockholders }\end{array}$ & The number of block holders owing at least $5 \%$ & $\begin{array}{l}\text { Folta and O'Brien } \\
(2008)\end{array}$ \\
\hline \multicolumn{3}{|c|}{ 3. Decision related factors } \\
\hline Prior experience & $\begin{array}{l}\text { Number of technologies } \\
\text { The count of all total acquisitions that the focal } \\
\text { firm made in } 3 \text { years prior to the focal year }\end{array}$ & $\begin{array}{l}\text { Vassolo et.al } \\
\text { (2004); Folta and } \\
\text { O'Brien (2008); } \\
\text { Reuer and Leiblein } \\
(2000)\end{array}$ \\
\hline Relatedness & $\begin{array}{l}\text { Distance between target industry and the firm's } \\
\text { industry }\end{array}$ & $\begin{array}{l}\text { Folta and O'Brien } \\
\text { (2004); Folta and } \\
\text { O'Brien (2008) }\end{array}$ \\
\hline Partners' similarity & $\begin{array}{l}\text { Dummy variable; coded } 1 \text { if the partners are } \\
\text { from the same industry } \\
\text { The common technological domains among } \\
\text { partners }\end{array}$ & $\begin{array}{l}\text { Folta (1998) } \\
\text { Vassolo et.al (2004) }\end{array}$ \\
\hline Foreign transaction & Dummy variable; coded 1 if partners are from & Vassolo et.al (2004) \\
\hline
\end{tabular}




\begin{tabular}{|l|l|l|}
\hline & different countries & \\
\hline Multinationality & $\begin{array}{l}\text { Dummy variable; coded 1 if the involved two } \\
\text { firms from the same country } \\
\text { The number of countries in which a firm had } \\
\text { foreign subsidiaries }\end{array}$ & $\begin{array}{l}\text { Folta (1998); Reuer } \\
\text { and Leiblein(2000) }\end{array}$ \\
\hline License & $\begin{array}{l}\text { Dummy variable; coded 1 if technology } \\
\text { licensing agreement was initiated }\end{array}$ & Vassolo et.al (2004) \\
\hline
\end{tabular}

The objective of this study is to evaluate the factors that affect the effectiveness of exercising strategic options. Yet analyzing all kind of strategic options will be very complicated. Therefore in this study we put some limitations. In literature some strategic decisions are considered as the competence building decision, for instance Sanchez and Heene (1997) considered takeover and alliance decisions as competence building decisions. Table 3 summarizes the strategic decisions considered as strategic options. We focus on the competence building process achieved by the strategic decisions such as mergers, acquisitions, joint ventures and strategic investments. These decisions are mainly based on the external growth (Huber and Meschi, 2000).

Table 3 Strategic Decisions Considered as Strategic Options

\begin{tabular}{|l|l|}
\hline $\begin{array}{l}\text { Type of the exercised } \\
\text { strategic option }\end{array}$ & Studies \\
\hline Equity alliances & Folta and Miller (2002), Vassolo et al. (2004), Folta (1998) \\
\hline Market entry & $\begin{array}{l}\text { Folta et al. (2006),Folta and O'Brien (2004), O'Brien et al. (2003), } \\
\text { Miller and Folta (2002), Dixit (1989), Campa (1993) }\end{array}$ \\
\hline Joint ventures & $\begin{array}{l}\text { Cuypers and Martin (2007), Reuer and Tong (2005),Kumar (2005); } \\
\text { Reuer and Leiblein (2000), Chi (2000), Chi and McGuire (1996), } \\
\text { Kogut (1991), Folta (1998), Hurry et al. (1992) }\end{array}$ \\
\hline Acquisitions & $\begin{array}{l}\text { Folta and O'Brien (2007), Folta and O'Brien (2008), Laamanen } \\
(1999)\end{array}$ \\
\hline
\end{tabular}

A firm can have these strategic options. Each strategic option has an advantage over these factors. Base on this idea the selection of strategic options has main two attributes: Environmental Attributes, and Decision Related Attributes. Internal factors will be same for a company; consequently strategic option will not be able to overcome the problems associated with internal factors. Therefore in this study internal factors that affect the performance of strategic options are not selected. The main criterion environment includes the sub-attributes industry uncertainty, industry generosity, irreversibility, industry size, industry concentration, industry type and number of rivals. Each of the strategic decision's attributes affects the performance of strategic option. For instance high level of uncertainty in the strategic option's industry increases the risks in the area but high generosity increases the value of strategic option. The main criterion Decision related factor includes the subattributes prior experience, partners' similarity, relatedness, foreign transaction, multinationality, license. In this area factors have a positive effect on the value of strategic option. For instance prior experience increases the strategic option value. Figure 1 gives this hierarchy among attributes. 


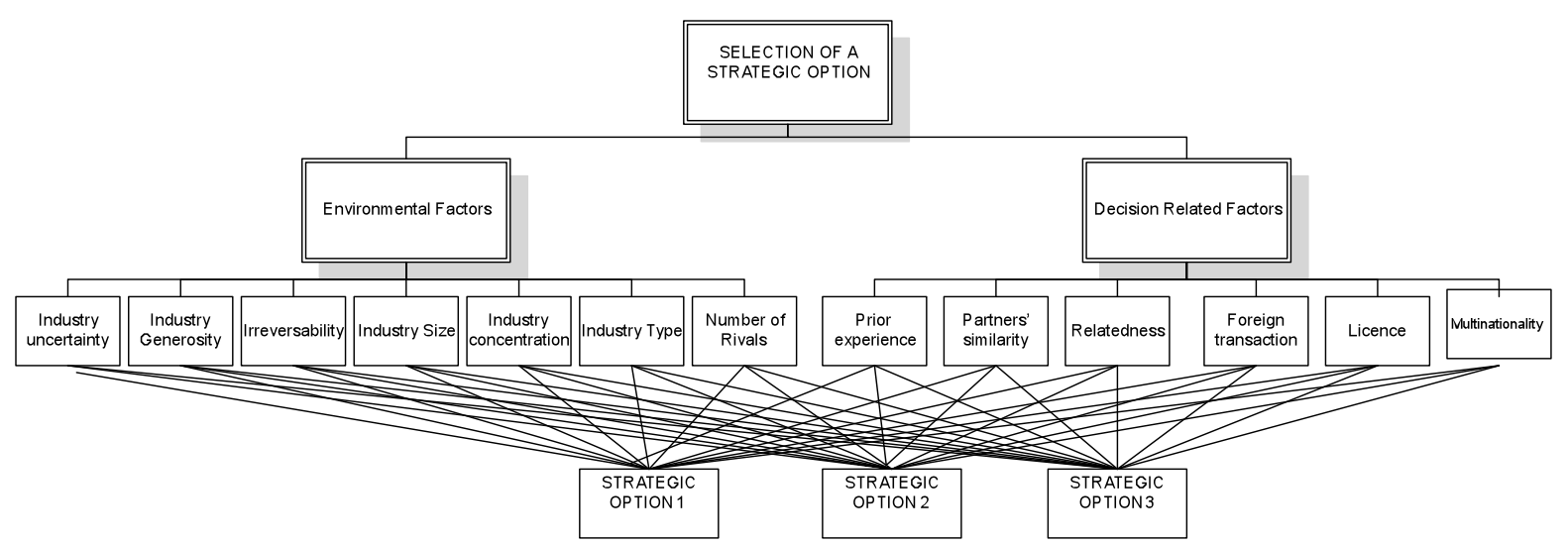

Figure 1 An Analytical Hierarchy Model For Selecting Among Strategic Options

\section{Implementation and ranking}

Three strategic options of an automotive company are evaluated using the Analytical Hierarchy Process given above. Taking into consideration the hierarchy in Figure 1, a questionnaire for fuzzy AHP were prepared to receive the individual weights of main and sub-attributes. Samples of questionnaire are given in Appendix. The results show that Decision Related Factors has 0.6 importance weight whereas Environmental factors have 0.4 importance weight. Table 3 shows the importance weights of sub factors.

Table 3 Importance weights of sub-factors

\begin{tabular}{|cc|}
\hline Sub-attribute & Importance weight \\
\hline industry uncertainty & 0.08 \\
industry generosity & 0.01 \\
irreversibility & 0.03 \\
industry size & 0.07 \\
\hline industry concentration & 0.05 \\
industry type & 0.06 \\
\hline number of rivals & 0.10 \\
\hline prior experience & 0.05 \\
partners' similarity & 0.11 \\
\hline relatedness & 0.12 \\
\hline foreign transaction & 0.08 \\
license & 0.12 \\
\hline multinationality & 0.01 \\
\hline
\end{tabular}

The results in Table 3 show that Strategic Option1 has the highest performance among all strategic options where Strategic Option2 is the third with corresponding priority weights in Table 4.

Table4 4 Results of AHP

\begin{tabular}{lc}
\hline & Priority Weights \\
\hline Strategic Option 1 & 0.41 \\
Strategic Option 3 & 0.34 \\
Strategic Option 2 & 0.25 \\
\hline
\end{tabular}




\section{Conclusion}

In this paper a model for selecting strategic options base on environmental and decision related factors has been presented. The model is based on the premise that strategic options should be considered via multiple criteria decision making methods.

Selecting strategic options is a complex problem in which many qualitative attributes must be considered. These kinds of attributes make the evaluation process hard. Hierarchical structure is a good approach to describe complicated system. AHP has the capability of taking pairwise comparisons of these attributes into account with a hierarchical structure. For further research a sensitivity analysis can be utilized in order to check the robustness of the model. Also a model which includes the internal factors can be utilized.

\section{APPENDIX}

With respect to the overall goal "selection of the strategic option",

Q1. How important is Environmental Factors when it is compared with Decision Related Factors?

\begin{tabular}{|c|c|c|c|c|c|c|c|c|c|c|c|c|c|}
\hline \multicolumn{2}{|c|}{$\begin{array}{l}\text { With respect } \\
\text { to: the } \\
\text { selection of the } \\
\text { best } \\
\text { performance } \\
\text { among faculty }\end{array}$} & \multicolumn{12}{|c|}{ Importance (or preference) of one main-attribute over another } \\
\hline 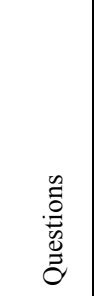 & $\begin{array}{l}\stackrel{\circlearrowright}{\Xi} \\
\stackrel{0}{E} \\
\stackrel{E}{E}\end{array}$ & 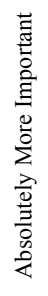 & 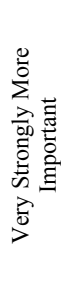 & 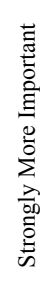 & 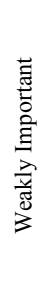 & 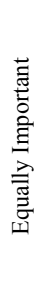 & 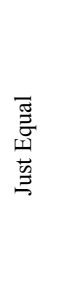 & 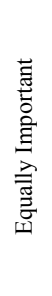 & 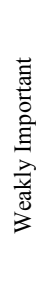 & 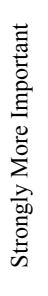 & 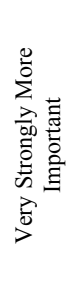 & 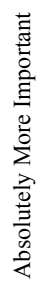 & 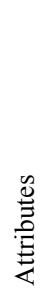 \\
\hline Q1 & $E$ & & & & & & $\checkmark$ & & & & & & DR \\
\hline
\end{tabular}

\section{With respect to the sub-attribute "prior experience"}

Q2. What is your preference on Option-1 when it is compared with Option-2?

Q3. What is your preference on Option-1when it is compared with Option-3?

Q4. What is your preference on Option-2 when it is compared with Option-3?

\begin{tabular}{|c|c|c|c|c|c|c|c|c|c|c|c|c|c|}
\hline \multicolumn{2}{|c|}{$\begin{array}{l}\text { With respect to: } \\
\text { Community service }\end{array}$} & \multicolumn{12}{|c|}{ Preference of one alternative over another } \\
\hline $\begin{array}{l}\frac{n}{\tilde{\sigma}} \\
\stackrel{\tilde{D}}{0} \\
\tilde{\Xi}\end{array}$ & 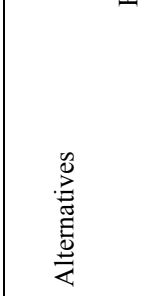 & 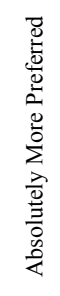 & 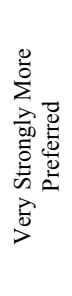 & 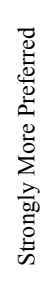 & 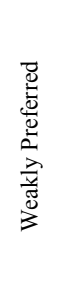 & 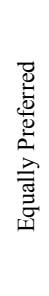 & 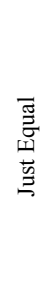 & 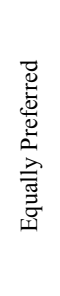 & 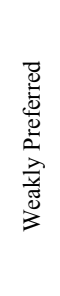 & 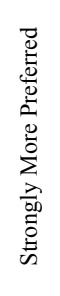 & 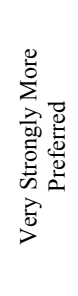 & 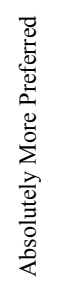 & 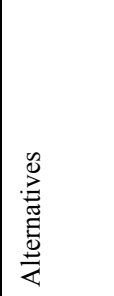 \\
\hline Q2 & Option-1 & & & & & & & & & & & $\checkmark$ & Option-1 \\
\hline
\end{tabular}




\begin{tabular}{|r|l|c|l|}
\hline Q3 & Option-2 & $\checkmark$ & Option-2 \\
\hline Q4 & Option-3 & $\checkmark$ & Option-3 \\
\hline
\end{tabular}




\section{REFERENCES}

Al-Shemmeri, T., Al-Kloub, B., Pearman, A. (1997) Computer aided decision support system for water strategic planning in Jordan. European Journal of Operational Research, 102 (3), 455-472.

Bayazit, O., Karpak, B., \& Yagci, A. (2006). A purchasing decision: selecting a supplier for a construction company. Jornal of Systems Science and Systems Volume 15, Number 2 / May, 2006, 217-231.

Bernardo A.E., Chowdhry, B., 2002, "Resources, real options, and corporate strategy", Journal of Financial Economics 63, 211-234

Borenstein and Betencourt, 2005. A multi-criteria model for the justification of IT investments. INFOR, 43, 1-21.

Büyüközkan, G., Feyzioğlu,O. Nebol, E. (2008) Selection of the strategic alliance partner in logistics value chain. International Journal of Production Economics, 113(1), 148-158.

Campa JM. 1993. Entry by foreign firms in the United- States under exchange-rate uncertainty. Review of Economics and Statistics 75: 614-622.

Chandrasekaran, G.and Ramesh R. (1987)Microcomputer based multiple criteria decision support system for strategic planning Information \& Management, 12(4), 163-172.

Cheng, E.W.L., Li, H. (2007)Application of ANP in process models: An example of strategic partnering. Building and Environment, 42 (1), 278-287.

Chi T. (2000) Option to Acquire or Divest a Joint Venture. Strategic Management Journal, 21(6), 665-687

Chi, T.; McGuire, D. J. 1996 Collaborative ventures and value of learning: Integrating the transaction cost and strategic option perspectives on the choice of market entry modesJournal of International Business Studies; 27, (2). 285-307.

Cuypers, I.R. and Martin, X. (2007). Joint ventures and real options: An integrated perspective. In Reuer, J., Tong, T. (Eds.) Advances in Strategic Management, 24, 103-144. Elsevier.

Datta, V., K.V. Sambasivarao, R. Kodali, and S.G. Deshmukh, 1992, Multi-attribute decision model using the analytic hierarchy process for the justification of manufacturing systems. International journal of production economics 28:22, 227-234.

Ding, J-F; Liang, G-S (2005) Using fuzzy MCDM to select partners of strategic alliances for liner shipping. Information Sciences, 173:1-3, 197-225

Dixit AK. 1989. Entry and exit decisions under uncertainty. Journal of Political Economy 97: 620638.

Firouzabadi, S., Henson,B., Barnes, C. (2008) A multiple stakeholders' approach to strategic selection decisions. Computers \& Industrial Engineering, 54(4), 851-865.

Folta, T. B. (1998) Governance And Uncertainty: The Tradeoff Between Admınıstratıve Control And Commitment. Strategic Management Journal,19 (11), 1007-1029.

Folta, T. B. , Johnson, D.R., and O'Brien, J.(2006). Uncertainty, irreversibility, and the likelihood of entry: An empirical assessment of the option to defer. Journal of Economic Behavior \& Organization, 61(3), 432-452

Folta, T. B.; and Miller, K. D. (2002). 'Real options in equity partnerships.' Strategic Management Journal, 23(1): 77-88.

Folta, T. B.; O'Brien, J. P. (2004). 'Entry in the presence of dueling options.' Strategic Management Journal, 25(2): 121-138

Folta, T. B.; O’Brien, J. P. (2007).Market Versus Managerial Valuations of Real Options. In Reuer, J., Tong, T. (Eds.) Advances in Strategic Management, 24, 199-224. Elsevier.

Folta, T. B.; O’Brien, J. P. (2008). Determinants of firm-specific thresholds in acquisition decisions. Managerial and Decision Economics, 29 (2/3), 209-225.

Hurry D., Miller, A.T. and Bowman, E.H. (1992). Calls on highğtechnology : Japanese exploration of venture capital investments in the United States. Strategic Management Journal, 13(2), 85-101.

Islei, G., Lockett, G., Stratford, M. (1990) Resource management and strategic decision making in industrial R\&D departments: : Decision support using judgmental modelling in the chemical industry. Engineering Costs and Production Economics, 20 (2), 219-229. 
Kasanen,E., Wallenius, H., Wallenius,J., Zionts, S. (2000) A study of high-level managerial decision processes, with implications for MCDM research European Journal of Operational Research, 120 (3), 496-510.

Kogut, B. (1991). Joint Ventures and the Option to Expand and Acquire. Management Science, 37 (1), 19-33.,

Kogut, B. and Kulatilaka, N. (2001). Capabilities as real options. Organization Science, 12 (6), 74458.

Kumar, M.V. S., 2005 "The value from acquiring and divesting a joint venture: A real options approach", Strategic Management Journal, 26, 321-331

Kyläheiko, K., Sandström, J. (2007). Strategic options based framework for. management of dynamic capabilities in manufacturing firms.Journal of Manufacturing Technology Management, 18(8), 966-984.

Laamanen, T. (1999) Option nature of company acquisitions motivated by competence acquisition. Small Business Economics, 12(2), 149-169.

Maritan, C., Alessandri, T. (2007)Capabilities, Real Options, and the Resource Allocation Process. Advances in Strategic Management, 24, 307-332

McGrath, R.G., Nerkar, A. (2004). Real Option Reasoning and A New Look at the R\&D Investment Strategies of Pharmaceutical Firms. Strategic Management Journal, 25, 1-21.

McGrath, R.G., Ferrier, W.J. , Mendelow, A.L. (2004) Real Options as Engines of Choice and Heterogeneity. Academy of Management Review, 29 (1), 86-101.

Miller, K. D.; and Folta, T.B. (2002). 'Option value and entry timing.' Strategic Management Journal, 23(7): 655-665.

O'Brien, J.P., Folta, T.B., Johnson, D.R. (2003) A Real Options Perspective on Enterpreneural Entry in the Face of Uncertainty. Managerial and Decision Economics, 24, 515-533

Pandza, K., Horsburgh, S., Gorton, K. \& Polajnar. (2003). A real options approach to managing resources. and capabilities. International Journal of Operations \& Production Management, 23(9), 1010-1032.

Reuer J.J., Leiblein M.J. (2000). Downside Risk Implications of Multinationality and International Joint Ventures. Academy of Management Journal, 43, 203-214.

Reuer, J.J. and Tong, W.T. (2005). Real options in international joint ventures. Journal of Management, 31 (3), 403-423.

Saaty, T. L. (1980). The analytic hierarchy process. New York: McGraw-Hill.

Sanchez R. (1993). Strategic flexibility, firm organization, and managerial work in dynamic markets: a strategic options perspective. Advances in Strategic Management 9: 251-291.

Sanchez R., Heene, A. (1997). Reinventing Strategic Management: New Theory and Practice for Competence-based Competition. European Management Journal, 15 (3), 303-317.

Sanchez, Heene, A. and Thomas, H. (Eds.) (1996) Dynamics of competence based competition: Theory and practice in the new strategic management. Oxford:Elsevire Pergamon Press.

Sanchez, R .(2003). Integrating Transaction Costs Theory and Real Options Theory. Managerial and Decision Economics, 24, 267-282.

Sanchez, R. (1997). Preparing for Uncertain Future. International Studies of Management \& Organization, 27(2), 71-94.

Sanchez, R. (2004). Understanding Competence-Based Management Identifying and Managing Five Modes of Competence. Journal of Business Research 57, 518- 532.

Tong, W.T., Reuer, J.J. (2008) Firm and Industry Influences on the Value of Growth Options. Strategic Organization, doi:10.1177/14761270006061033.

Vassolo, R. S., Anand, J. ve Folta. T. B. 2004. "Non-Additivity in Portfolios of Exploration Activities: A Real Options-Based Analysis of Equity Alliances in Biotechnology." Strategic Management Journal 25: 1045-61. 